\title{
HISTORICAL LITERATURE AS AN ENCULTURATION OF EDUCATION IN LOCAL WISDOM OF KINGDOM FAMILY IN JAVA
}

\author{
Muhammad Iqbal Birsyada \\ University of PGRI Yogyakarta \\ E-mail: iqbal@upy.ac.id \\ Darsono \\ University of PGRI Yogyakarta \\ E-mail: pakdhedarsono2014@gmail.com \\ Siswanta \\ University of PGRI Yogyakarta \\ E-mail: siswanta@upy.ac.id \\ Sudartoyo \\ University of PGRI Yogyakarta \\ E-mail: dartoyo@upy.ac.id \\ Juang Kurniawan Syahruzah \\ University of PGRI Yogyakarta \\ E-mail: juang@upy.ac.id
}

\begin{abstract}
Abstrak
Literatur historis historis memiliki akar budaya terutama dalam pengembangan karakter nilai-nilai kearifan lokal. Selain itu pengembangan budaya sejarah sastra dapat menjadi salah satu acuan dalam proses penulisan historiografi. Penelitian ini bertujuan untuk menemukan nilai-nilai kearifan lokal dalam karya sastra sejarah. Penelitian ini menggunakan metode historis. Kesimpulan dalam penelitian ini menemukan bahwa literatur sejarah yang berkembang di Jawa mengekspresikan puisi penulis sastra. Secara kultural, isi literatur sejarah mencerminkan strategi enkulturasi nilai-nilai kebijaksanaan keluarga kerajaan kepada masyarakat Jawa. Saran penelitian ini adalah untuk mengembangkan studi lebih lanjut dari bentuk-bentuk lain enkulturasi dalam literatur sejarah untuk pengembangan nilai-nilai kearifan lokal masyarakat Jawa.
\end{abstract}

Kata kunci: Sejarah Sastra, Budaya, Pendidikan Kearifan Lokal, Keluarga Kerajaan, Jawa

\begin{abstract}
Historically historical literature has cultural roots especially in the development of the character of the values of local wisdom. In addition to the development of literary history culture can be one of the references in the process of writing historiography. This study aims to find the values of local wisdom in the work of historical literature. This research uses historical method. The conclusion in this study finds that the historical literature that developed in Java expressed the literary writer's poetry. Culturally, the contents of historical literature reflect the strategy of enculturation of the values of the royal family's wisdom to the Javanese community. The suggestion in this study is to develop a further study of other forms of enculturation in historical literature in the development of local wisdom values of the Javanese community.

Keywords: Literature History, Enculturation, Local Wisdom Education, Royal Family.
\end{abstract}

\section{INTRODUCTION}

Culturally, the development of Hindu-

Buddhist culture declined after the collapse of Majapahit kingdom.
Nevertheless, the development of Hindu culture during the period of Islamic empires in Java continuously aligned with the socio-cultural conditions of Javanese society (Berg, CC, 1974). The development 
of culture in the next process is divided into two parts. The first part is the great culture in this case represented by the culture of the palace. Great culture emerges through forms of historical literary works that explain the genealogy of the opening of a region or kingdom. This literature also strengthens the legitimacy of the royal family power through various symbols of the lineage of the Javanese kings who reached the Prophet Adam and the Gods as found in the Hindu cultural tradition (Birsyada, 2016).

After the fall of the Majapahit kingdom, Demak and Mataram Islam emerged carrying the mission of cultural transformation as well as politics and ideology (Birsyada, 2012). In the time of the Islamic Matramese kingdom, historical literature such as the Babad Tanah Jawi was made by pujanggan of the royal family to strengthen the legitimacy of political power and royal ideology (Birsyada, 2016). However, Resi (2010) finds that in historical literature other than loading the genealogy of the royal family also contains the structure of Javanese human life. Human life is from immanent, existential, and essential to the last path that is the essence of human life that is we are one with God. Hoesen Djajadiningrat was the first native scholar to examine historical literature. His findings explain that historical literature such as Babad Banten reflects the style of public expression of thought at that time which still tends to be mystical and syncretic. Nevertheless historical literature cannot simply be ruled out in the treasury of historical sources (Rishi, 2010).

The above view of Hoesen Djajadiningrat is supported by Suryo (1988) who argues that historical literature is the cultural heritage of the archipelago. Historical literature can serve as a source of history supported by other relevant sources. According to Resi (2010) the life cycle of historical figures contained in Javanese literature reflects the structure of life which in Javanese terminology is called Manunggaling Kawulo lan Gusti. (Rishi, 2007; Rishi, 2010). Such a cycle in the study of Javanese culture is then referred to as the science of paran dumadi which shows the ideological value of Kejawen. The origin of life is the beginning of human life until the process leading to death back to the Lord. The concept of Kejawen is then pinned on historical literature that many acculturate between Hindu-Buddhist cultures with Islam.

Kroom (1956) explains the Hindu tradition in historical literature is still very strong. The rise of Hindu gods like Winsu in Javanese literature shows that the Hindu concept of thinking is still very strong. Through the genealogy of Lord Vishnu then bring up the Javanese kings. So almost all of Java's kings are none other than descendants of Vishnu. Politically, the aim of making the genealogy of the lineage of Javanese kings to the gods is to reinforce 
the legitimacy of power. The king in the Javanese tradition is symbolized by the cosmic center which means the protector and guardian of all mankind. However, the values in historical literature developed by the royal family in practice do not always get a good response from the Javanese community. The royal system divides the social class of society that is the royal family with the common people.

The formation of the two social classes above causes both cultures who was born both from the kingdom and the common people's class (wong cilik) developed independently. The class of youth or wong cilik is in practice incapable of interpreting and even counting the grammar as developed in the royal tradition. In the 18th century the Javanese were still illiterate. Lower class people only understand the story of history through pitutur from one generation to the next. These social class differences then confirm the position of each developing culture. The emergence of cultural transformation from Hindu-Buddhism to Islam is not necessarily followed by an egalitarian style of community life. The rise of the Islamic kingdoms has indirectly re-established the old feudal tradition. King, Priyayi and Kawula is a new class formed on the Java community in the era of Islamic Mataram (Resi, 2007; Resi, 2010; Woodward, 2004; Kuntowijoyo, 1991; Birsyada, 2016; Kersten, 2013). Culturallyhistorically, historical literature living in a class of people or subjects is poorly developed. The class of subjects is incapable of consuming the symbols of elitist language as found in the kingdom.

Therefore culturally historical literature is often considered as a means of legitimacy of the king and gentry class against class subjects (Woodward, 2004: 51; Kuntowijoyo, 1991; Kuntowijoyo, 2016). Small traditions that develop in society just more show its existence than the great tradition as the values contained can be historical literature. Great traditions such as history literature practically only thrive and earn a good reception within the royal family. Because inside the palace is not so strong social class fort between king, royal family and royal servant (Birsyada, 2016). Theoretically, literary history than can be used as a source of historical writing can also convey the expression of feelings experienced by the author of literary works against the state of the social environment they experienced included as a tool to criticize the life of the social environment of the palace aberrant (Birsyada, 2012; Birsyada, 2016 ). Ronggowarsito for example, criticizing the lifestyle of the family of Surakarta palace through the literature of Serat Kalatidha as follows: Mangkya darajating praja Kawuryan wus sunyaturiReport of pangrehing ukar aKarana without palupi Atilar silastuti Sujana bachelor of kalulun when tida Tidhem tandhaning dumadi Ardayengrat 
dene karoban rubeda (Serat Kalatidha Ranggawarsito) Meaning: State Situation Currently, Has Degraded the state has broken, Because there is no that can be followed anymore. Many people left the tradition. The condition is inconvenience because world is full of hassles (Widyawati 2009) .Writing in the temple of Fiber Kalatidha Ronggowarsito above reflects that sang- The poet of his heart feels uneasy because of his unsafe state.

Therefore, as a poet, Ronggowarsito social resistance through the literary works of Serat Kalatidha. It was done as an expression of concern as well as concern for the behavioral situation of the royal family. Fiber Kalatidha of this may be one example that of literary works palace has not always been a tool of legitimacy of royal power, but also become a resistance against lifestyle conditions deteriorated royal family (ethical crisis). Some old literary works such as Babad Jaka Tingkir Malangsumirang Fiber, Fiber Cebolek also an expression of resistance-resistance against hegemony mentality monarch deemed to have deteriorated. In addition to Serat Kalatidha, Kuntowijoyo (1991) also analyzed the story of Haji Mutamakin's resistance to the dominance of the clergy of the Surakarta court. Florida (2003) and Sastronaryatmo (1981) analyzed the resistance of Javanese Islamic tarekat figures such as Sheikh Siti Jenar, Ki Ageng Pengging against the domination of power.
Historically, in the tradition of Javanese leadership, the King was symbolized to gain legitimacy through magical powers or kasekten as well as genealogical genealogies of the gods or people who are considered sacred (the Prophet). Therefore, in order to legitimize its power every king will gain the sacredness of obtaining royal revelation (Birsyada, 2016). It is through the sanctity that the essence of literary history essentially tends to confirm the legitimacy of the king's power genealogy. So, the conception that tried to be developed is the image of the king as a figure who is considered to have the sanctity of supernatural powers that are not owned by others, also become role models of kawulanya. The king has received the royal court's revelation to lead his kawulanya, meaning the monarch absolutely obtains the legitimacy of his absolute power to rule his people.

To strengthen this legitimacy, the king ordered literary poets to make literary works that affirm the sanctity and legitimacy of his apocaly (Kartodirdjo, 1984) With Fortes's view, Fortes argues that in traditional societies the problem of the origin of hereditary family was very powerful in perpetuating the position of ruler (Balandier, 1986: 66-67). Because the offspring or kinship is one means of strong legitimacy in perpetuating the power of dynasties (Woodward, 2004: 53-54). Literary works are shaped and made in 
such a way as to cultivate awareness, especially the king's servants to have an attitude of loyalty, obedience and obedience to the king's order and support the superior in achieving the goal in religious teachings called Satya Bela Bakti Prabu (Widyawati, 2010: 38-39). Historical literary works made by the court palace servants of palace courts were made to cultivate the mechanical and magical awareness of Javanese society. In the Weberian tradition, this awareness can be done if in the history story there is one public figure who has magical and charismatic power is high then in religious thing by the surrounding community. On the basis of the legitimacy of this sanctity that character can lead and mobilize society to create social order (Ritzer and Goodman, 2004). According to Resi (2010:

4) the work of historical literature as in the form of fiber and babad are often also said as a new genre in the traditional literary heritage of the archipelago. Some experts mention that this type of literature emerged along with the development of Islam in the archipelago around the XIV century and XV AD. Although the statement is not entirely true, because in Java in the Hindu period has been written Book of Pararaton, which has the characteristics of literary works as intended. Similarly in Bali, Balinese people who until now most of the population still adhere to the Hindu religion that their ancestors have also written Babad Buleleng. However, it must be admitted also if the arrival of Islam has introduced Jawi writing to the public who contributed greatly to the writing of literary works. Cultural transformation from Hinduism into Islamic tradition provides new variants in Javanese literary tradition. Historical literature in the Islamic era is more dominant to express the way of thinking of Javanese Islam (Suryo, 1998). This distinction also causes a new variant of the Islamic cultural pattern of the puritan (Rishi, 2007; Birsyada, 2016). Each shows the expression of soul and ideology in every historical literature that is made. An example is at time writing. In Hindu tradition it usually uses Saka year number. While in Islamic tradition wearing Hijri calendar.

The establishment of Islamic empires increasingly reinforced cultivated ideology in the development of literary writing history in Java. These ideas are then structured into the Javanese community of proponents of Islamic culture. Theoretically, based on the contents of literary history of the archipelago contains several elements that reflect the genre of the work. At least there are three elements that characterize the literary work of archipelago history, which is to tell the origin of the king, the story of the opening of a country, and the arrival of Islam in the archipelago. In the three elements, the author of literary history always uses myth as a complement. Myths are used extensively by the author so 
often said to be an integral part in the literary work of the history of the archipelago. These myths are used in certain parts of the story and each shows its relationship to the cultural background and thoughts that influence it (Rishi, 2010).

Literature in the history of the archipelago in the form of fiber, seclusion, and chronicle is a more literary work written at the palace. As a literary work written on the order of the king of this work cannot be released with matters relating to the origin of the king. The story of the king's ruling origins is the main ingredient in the work of historical literature. The author of historical literature puts his own story on the king's origin. As an example in the script of Babad Kraton or commonly called Babad Tanah Djawi Tumenggung Jayaningrat (1777), Rass, JJ (1987) and (in Wiryapanitra, 1993) it is explained that the origin of the King of Java is the descendant of Prophet Adam lowered other prophets, The prophet lowered the gods, to the god Vishnu (Rishis, 2010). Lord Vishnu dropped figures in puppetry until the Javanese kings. Babad Tanah Jawi seeks to integrate the legitimacy of the values of Hinduism and Islam. So the power of the king is considered legal according to Hindu and Islamic traditions because the path of the king's genealogy is the descendant line of Prophet Adam (Islam) is also the descendant of the Gods (Hindu). King as the center of the cosmos on earth as khalifatulloh fil ardhi is the umbrella for the genealogy of Javanese Hindu tradition and Islamic tradition. The origins of the king's descendants described in the literary works of history, in the ranks of kingship lineage with very coherent and neat.

The lineage of the descendants is arranged by the author (the court of the court) so that the position and legitimacy of the king who ordered the writing can be held accountable. The genre flow made in the story. At the beginning of the story is usually a bit blurry and the names are often alien and less familiar. Babad Demak, Babad Demak is one of the examples of historical literary works that narrates the opening of a country territory as well as explaining the origins of the Javanese Kings until the Islamic Mataram Kingdom (Sastronaryatmo, Moelyono, 1981; Riyadi, Selamet and Suwaji.1981; Tumenggung Jayengrat, 1777; Rass, JJ, 1989). Suryo (1998) views Javanese literature is an important historical and cultural document for the Javanese and Nusantara people, as it contains Islamic process in Javanese society. So Javanese literature is a cultural document recording the profound events of Islamic culture, especially in the process of Islamitation and the process of dialogue between Islam and Java, as well as the process of the formation of JavaneseIslamic or Javanese-Javanese culture to replace the previous Javanese-Hindu culture. The process of acculturation, 
enculturation and syncretization of Islamic and pre-Islamic cultures can basically be tracked in this traditional literary work. By exploring the history and culture of the literary works of babad, it can be used as one of prototype identity of the nation's identity of development and globalization era. Reflecting from the above view it is quite clear that a Javanese literary work was made as one of the efforts of Javanese cultural enculturation made by the poet and the palace which is continuously socialized to society. The culture of cultural enculturation is then a cultural process (Koentjaraningrat 1986: 233) or cultural socialization (Koentowijoyo 1987: 43). In the process of cultural enculturation, an individual learns and adjusts his or her own minds and attitudes with the customs, the norms and rules of the system that live in his culture. The result of the cultural process that took place in the Java community then undergoes dialectical processes and becomes an objective knowledge of individuals and communities (Berger and Luckmann, 1990; Koentjaraningrat, 1990).

\section{RESEARCH METHOD}

The research method used in this study uses historical methods. The research procedure in the historical method is carried out through the following stages: as the initial stage is the collection of resources in accordance with the research problems both primary and secondary sources that are then called heuristic. At this stage we seek and collect data and historical sources or materials for historical evidence such as: literary works of chronicles, letters and other reference books that will have a connection with the issues to be discussed. The search is done in several places such as the museum of Sonobudoyo Yogyakarta, the Museum in Yogyakarta Sultanate Palace, Surakarta Radyapustaka Museum. At this stage, researchers are looking for literary literatures that are books related to the problem of research. Resources used in library research are useful as comparative, complementary and analyzer to deepen the issues discussed. The next stage is the source criticism, namely assessing the state and authenticity of sources found both externally and internally. Source criticism can be proven if these sources are truly historical facts. External criticism is used to determine the authenticity and authenticity of historical sources. It is to determine whether the source is the true source needed or not. External criticism is used to answer three basic points: The originality of the source we want; whether the source corresponds to its original or artificial; and whether the source is intact or has been varied (Wasino, 2007; Garaghan, S.J., Gilbert J.A, 1957; Gottsschalk, 1986). While internal criticism is done after the author completes an external criticism, having known the 
sources of authority, internal criticism is done. Internal criticisms are used to prove whether these sources are truly historical facts. Then do internal critique compare to one data with another data through the study of the lust. The third step is the stage of interpretation or historical interpretation that has been selected before. Interpretation is a way of determining the interconnected intentions of the facts obtained after accumulating some information on historical events being investigated. An event in order to be a good historical story hence need to be interpreted the various facts that are separated from one another should be linked and linked thereby forming a united one.

In the process of interpretation not all facts can be included but must be selected which is relevant to the story description to be compiled. The last stage is the preparation or writing of history that is the preparation of facts in a complete synthesis as a unity in the form of historiography. Historiography is a historical story of the above interpretation of the results. Here the author clearly makes historical stories according to the facts obtained during the study. The results of historical writing conducted using a descriptive approach. The data source referenced research derived from primary and secondary sources in the form of literary history, as Babad Tanah Jawi, Babad Kraton, the Chronicle Demak, Babad
Jaka Tingkir, Fiber Kalatidha, Fiber Sumiray and several secondary sources of the previous research on enculturation education of local wisdom The Javanese community. The rationale above is considered sufficient to be used as a reference in this study until this study can describe and analyze the historical development of Javanese literary works as an enculturation of local Javanese wisdom education. With this historical approach is expected to produce an explanation that is able to express the process of cultural enkulturasu Javanese literary work in local wisdom education Java community. In that regard the dominant factors that need to be tracked is important about the historical sources closer to the facts sejarah.

\section{RESEARCH FINDING AND DISCUSSION}

The emergence of Islamic society Demak as a base to make a religious conversion at the same time Hindu-Buddhist culture that has long been awakened in Lifestyle patterns of the Javanese who have been hereditary. The Hindu and Buddhist cultures of the Majapahit era have experienced a battle with Islamic culture (Asya'arie, 2002: 18-19). The conversion of religion as well as culture has implications for the shift from Hindu and Buddhist cultures to an Islamistent culture. Demak and Mataram show the turning point of Islamic culture, especially in the field of literary writing. Javanese literary works 
created in this era of Islamic Empire show its existence as part of the enculturation of Islamic culture. Literary works in this era dominated by Suluk, Fibers and chronicle therein contains elements the values of Sufism, Ethics and mystical Javanese who would later become local knowledge for the Java community (RASS JJ, 1987; Suryo, 1998; Florida, 2003; Woodward, 2004; Rishi, 2007). Literary works developed in the era of the Islamic empire in Java according to its contents are divided into two characters. First is a literary work that shows genealogy and legitimates the king's power.

This type of literary work supports and affirms the legitimacy of the king's authority over the subjects in which the king other than as a holder of authority over government as well as the representative of God on earth which is often called khalifatulloohi fil ardhi. Babad Tanah Jawi, Babad Kraton, Fiber Wedhatama, Wulangreh Fiber, Fiber Kalatidha, Chronicle Demak and Babad Jaka Tingkir were born in the era of Islamic Mataram as examples of how the terms of its contents more confirmed the legitimacy of the position of royal power. Affirmation can be seen from the narrative of the king of Mataram king to the king Brawijaya Majapahit. From the side of Islam genealogy of the kings of Mataram to Prophet Muhammad SAW. And in terms of Kejawen genealogy Mataram kings until the path of the Gods of Hindu until Nabi Adam
(Sastronaryatmo, 1981; Gina 1981; Riyadi, 1981; Rass JJ, 1987; Kuntowijoyo, 1991; Florida, 2003; Woodward, 2004; Kuntowijoyo, 2006; Rishi, 2007). If in the above explanation explained that the characteristics of Javanese literary works born by court poets in terms of content more reflect the genealogy and legitimacy of the king's power. So on the second characteristic, Javanese literature also shows criticism in the king's reign. Literary works such as Suluk Malangsumirang, Siti Jenar Fiber, Fiber Cebolek, Babad Jaka Tingkir, and Fiber Kalatidha is one example Javanese literature that it contains a lot of criticism in the governance of the palace. In the narrative of historical literature, the values of local wisdom can be seen from the content of the story that contains many noble pitutur science as well as symbolically teach the values of teaching manunggaling kawula lan gusti.

Babad Tanah Jawi Ras, JJ (1987), for example, tells the local wisdom of ethical and moral values in the form of story of relationship between kawula and gusti or the people with their king (Rishi, 2007, Rishi, 2010). Babad Jaka Tingkir is more to challenge tradition (Florida, 2003). Wedatama fibers are more spiritual and mystical (Mangkunegaran IV, 1926). Based on the above view can be concluded that the model of local wisdom education that is enculturated through literary works of history through literary forms of fiber, suluk and babad can be an ideology of the 
way of thinking Javanese palace era Mataram Islam. The enculturation model of local wisdom of Javanese society which is listed in the history literature is as a form of expression of soul of Javanese literary author. Starting from the thoughts above, Rishi (2007: 2010) finally revealed that the Javanese will always maintain the harmony and balance of various elements that exist (micro and macro kosmos). With so the life of the universe will be safe again, peace and serenity is the dream of life and purpose of life of the Javanese "memayu hayuning bawana". This life-balance teaching which is attempted to be enculturated through Javanese literature is none other than the essence of the ideological philosophy of the ideology of be one with God.

\section{CONCLUSION}

The work of historical literature is an arrangement of heterogeneous parts. The materials come from oral traditions and written traditions that interact with each other. The process of writing historical literature, first in stacking the number of years in fantasy. In those years were placed kingdoms with a list of its king. Then in the form of the frame in the insert stories taken from the tradition of oral and written traditions that already exist in Java. Starting from the above understanding in approaching the contents of the literary work of the chronicle must be connected with the culture that gave birth to it. Historical literature can be used as a source of history, but must also be controlled with other relevant sources of research. The education of local wisdom that wants to be enculturated in Javanese literature is related to the teachings of be one with God, spiritual and mystical teachings as well as Javanese moral ethics. This teaching gives meaning to the Javanese attitude of life in order to be aligned and in line between society and its leader. The doctrine is also vertical, that is putting forward the violence between man and his God. To achieve such harmony the manuscripts and attitude of the Javanese life must be able to curb his personal desires. By way of arrogance, the pattern of life is concerned, not too pursuit of the world but prioritizes the substance of the quality of life attitude that based on customary norms and religious norms. Humans who are already in this stage can already be said with predicate Jawani or in religious sociology called transcendent essential. Suggestions in this study is to socialize these findings to the general public as an enlightenment as well as add a new treasury knowledge for the historiography of the archipelago. Second, the local wisdom education contained in the literary work of history can be used as part of the cultural identity of the archipelago. Thirdly, the study of Javanese literature can serve as an input to the 
government in order to develop local content in schools throughout Java.

\section{ACKNOWLEDGEMENT}

Early version of the article also has presented on international conference of education and science in University of PGRI Yogyakarta, July 20, 2017.

\section{REFERENCES}

Asy'arie. Musa. (2002). Menggagas Revolusi Kebudayaan Tanpa Kekerasan. Yogyakarta: LESFI.

Berger, Peter L. \& Thomas Luckman. (1990). Tafsir Sosial atas Kenyataan: Risalah tentang Sosiologi Pengetahuan (diterjemahkan dari buku asli The Social Construction of Reality oleh Hasan Basari). Jakarta: LP3ES

Balandier, Georges. (1986). Antropologi Politik. Jakarta: CV.Rajawali.

Berg, C.C.(1974). Penulisan Sejarah Jawa. Terjemahan Gunawan. Jakarta: Bhatara. Para Penulis Babad Dan Implikasi Terhadap Pendidikan Sejarah. Tesis Unnes. Tidak diterbitkan.

Birsyada, Muhammad lqbal. (2012). Peristiwa Konflik Pecahnya Keluarga Di Kerajaan Demak Dalam Persepsi Penulis Babad. Tesis UNNES.

Birsyada, Muhammad lqbal. (2016). Islamisasi Di Jawa: Konflik Kekuasaan Di Demak. Yogyakarta: Calpulis.

Birsyada, Muhammad lqbal, dkk. (2016). Pemikiran Keluarga Mangkunegaran. Jurnal Pramita Jurusan Sejarah Universitas Negeri Semarang volume 2.

Birsyada, Muhammad lqbal, dkk. (2016). Bisnis Keluarga Mangkunegaran, Jurnal Penelitian Sosial dan Keagamaan Universitas Islam Negeri Walisongo Semarang volume 1.
Birsyada, Muhammad Iqbal. (2016). Budaya Keraton Pada Babad Tanah Jawi Dalam Perspektif Pedagogi Kritis, Jurnal Sejarah, Budaya dan Pengajarannya Universitas Negeri Malang nomor 2 tahun 2016.

Florida, Nancy K. (2003). Menyurat Yang Silam Menggurat Yang Menjelang Sejarah sebagai Nubuat di Jawa Masa Kolonial. Yogyakarta:Bentang Budaya.

Garaghan, S.J., Gilbert J.A. (1974). Guide to Historical Method. London: Macmillan Education LTD.

Gina, Dirgo Sabariyanto. (1981). Babad Demak II. Jakarta: Depdikbud.

Gottsschalk, Louis. 1986. Mengerti Sejarah. Jakarta :UI Press.

Kartodirdjo, Sartono. (1984). Kepemimpinan Dalam Dimensi Sosial. Jakarta: LP3ES.

Kersten, Carool. (2013). Review of Mark Woodward, Java, Indonesia and Islam. International Journal Shopia, Springer vol 52. HIm 209-212.

Koentjaraningrat. (1986). Pengantar Ilmu Antropologi. Jakarta; Aksara Baru.

Koentjaraningrat. (1990). Pengantar Ilmu Antrapologi. Jakarta: Aksara Baru.

Kroom, NJ. (1956). Zaman Hindu, terjemahan Arif Effendi. Jakarta: Pustaka Sarjana.

Kuntowijoyo. (1991). Paradigma Islam Intepretasi Untuk Aksi. Bandung: MIZAN.

Mangkunegara IV. (1926). Serat Wedatama Cetakan Pertama. Kediri: Tan Khoen Swie.

Moretono, Soemarsaid. (1989). Negara dan Usaha Bina Negara di Jawa Pada Masa Lampau: Studi Tentang Masa Mataram II, Abad XVI sampai XIX. Jakarta: Yayasan Obor Indonesia.

Mulder, Niels. (2001). Mistisisme Jawa Ideologi Di Indonesia.Yogyakarta: LKiS.

Ras,J.J. (1987). Babad Tanah Jawi De prosaversie van Ngabehi Kertapradja 
voor het uitgegeven door J.J.Meinsma en getranscribeerd door W.L.Olthof. Holland:Foris Publication.

Resi, Maharsi. (2007). Babad Kraton Analisis Simbolisme Struktural Upaya Untuk Memahami Konsep Berpikir Jawa Islam. Desertasi: UIN Sunan Kalijaga.

Resi, Maharsi. (2010). Islam Melayu vs Jawa Islam.Yogyakarta: Pustaka Pelajar.

Ritzer, dan Goodman,D. (2008). Teori Sosiologi Modern.Terjemahan Ali Mandan. Jakarta: Prenada Media Group

Riyadi, Selamet dan Suwaji. (1981). Babad Demak I. Jakarta: Depdikbud Proyek Penerbitan Buku Sastra Indonesia Dan Daerah.

Sastronaryatmo, Moelyono. (1981). Babad Jaka Tingkir.Jakarta: Depdikbud.

Soeratno, dkk. (2001). Khasanah Budaya Kraton Yogyakarta. Yogyakarta: UIN Sunan Kalijaga dan Yayasan Kebudayaan Islam Indonesia.

Soeratman, Soeratman. (1989). Kehidupan

Dunia Kraton Surakarta 1830-1939.

Yogyakarta: Taman Siswa.

Suryo, Djoko. (1998). Islam \& Khasanah Budaya Kraton Yogyakarta. Yogyakarta: Yayasan Kebudayaan Islam Indonesia.

Suwaji, Slamet Riyadi. (1981).Babad Demak I. Jakarta: Depdikbud.

Wasino. (2007). Dari Riset Hingga Tulisan Sejarah. Semarang: Unnes Press.

Widyawati R, Wiwin. (2009). Serat Kalatidha. Yogyakarta: Pura Pustaka.

Wiryapanita. (1993). Babad Tanah Jawa. Semarang: Dahara Prize.

Woodward, Mark R. (2004). Islam Jawa Kesalehan Normatif Versus Kebatinan. Yogyakarta: LkiS. 